\title{
Britain and the European Union
}

\section{6}

The background to British membership

The main impacts of British membership

The ways in which the party system has been affected by the EU

Future prospects for British involvement

\section{THE STORY OF BRITISH MEMBERSHIP}

\section{Britain stays out}

When serious discussions began to establish a successor to the European Coal and Steel Community (ECSC) in 1956, Britain made it clear that it was not intending to join any new organisation. Prime Minister Harold Macmillan, a Conservative who valued Britain's links with its empire and commonwealth, was opposed to the kind of close, supranational arrangement which Monnet and Schuman were proposing.

Macmillan also understood that, if Britain were to join the new Common Market, it would have to give up the system of trade preferences and agreements which it had with its allies in the Commonwealth. It would be seen as a betrayal to them if Britain were to abandon them in pursuit of its own interests in Europe. It was therefore decided to stay out and instead form a separate body. The Treaty of Rome was signed in 1957 with just six members.

\section{EFTA}

The European Free Trade Association (EFTA) contained seven members: Britain, Portugal, Sweden, Denmark, Norway, Austria and Switzerland. It had no political organisation and was therefore no more than a group of countries which agreed to reduce tariffs between them and so increase trade. Britain's agreements with the Commonwealth countries were preserved. 
EFTA reflected the large amount of trade which was carried out among the seven members, but it was never designed to be a rival to the Common Market. It was, in effect, an alternative economic system, joined by countries who opposed the idea of closer political union within a free trade area. It also recognised the fact that Britain's alliances should be maintained, while the traditional neutrality of Switzerland and the Scandinavian countries would no longer be compromised by a mere set of trade concessions.

\section{Britain's first two applications}

By 1961 Macmillan had come round to the idea that Britain's fortunes might improve as a member of the Common Market. The disbanding of the British Empire was now under way, so this represented less of a tie than before. Furthermore, Macmillan had become aware that Britain was not the world power it had once been. He managed to persuade a sceptical Conservative party that an application should be made. Negotiations began in 1961, only two years after EFTA had come into existence.

Three major obstacles existed which were likely to prevent British entry. They were:

1 French President Charles de Gaulle, a vehement nationalist, was determined that France should dominate the Community. If Britain were to join, he felt that it would be a powerful rival (West Germany, weakened by postwar division and the need for reconstruction, did not worry de Gaulle).

2 It was clear that Britain wished to preserve some of the Commonwealth preference agreements and so gain an advantage over the existing members. The existing members were certainly not willing to offer Britain a special deal.

3 In 1962 Macmillan concluded the Nassau agreement with the USA, whereby Britain would be able to stay in NATO, remain America's closest ally, but also retain an independent nuclear deterrent. Once again, France was suspicious of Britain's close relationship with the USA. Britain was not a serious European, they argued.

In consequence of this, France vetoed the British application for membership (to this day, applications for membership require a unanimous vote in the Council of Ministers). This action set back relations between France and Britain many years. The suspicion with which the two countries treat each other, has remained to this day. It also demonstrated Britain's attitude to Europe.

Macmillan's desire to preserve Britain's links with both the Commonwealth and the USA are seen by other countries as a lack of commitment to the European experiment. Like British-French tension, this has endured ever since. Margaret Thatcher's constant sniping at attempts to create a closer 
political union and her opting out of the Social Chapter and the single currency at Maastricht in 1992 have reminded Europeans that Britain remains suspicious of European integration. It was, therefore, no surprise that Britain's half-hearted attempts at entry were rejected.

In 1967 the British government, now led by Labour's Harold Wilson, renewed the application. Once again it was a less than enthusiastic attempt. There were a number reasons for this.

- A majority of Labour's membership was probably opposed to membership. It has to be remembered that Labour was further to the left of the political spectrum than it is today. The very large left wing of the party saw the European Community as a 'capitalist club', whose motives were to be suspected. The concept of free trade was seen as benefiting business at the expense of workers' pay and rights. Wilson, who stood in the middle of the party, could not be certain he could carry the day.

- There was a great deal of residual resentment at France, especially after the 1963 veto. De Gaulle was still in power and making negative noises about Britain.

Britain was entering a major economic crisis. In particular the UK balance of trade was in a very poor state so that the country was, effectively, bankrupt. Loans were negotiated from the International Monetary Fund (IMF) and sterling was devalued by nearly 15 per cent. This was therefore hardly an auspicious time to be undertaking such a radical new project.

Wilson hoped that British membership might provide a long-term solution to its economic problems. By comparison, the members of the Community were doing extremely well, with faster growth rates than Britain, falling unemployment and a surge in trade. However, de Gaulle exercised his veto once again, so Britain was left almost alone to try to solve its problems.

\section{Britain joins}

By 1971 Britain was led by Edward Heath, a Conservative Prime Minister who was deeply committed to the European ideal. He was a more internationally minded prime minister than any in Britain since Churchill who had retired in 1955. At the same time de Gaulle had gone, ousted during a period of political unrest and violence in 1968-69.

The year 1971 also saw the deepening of a recession which affected the whole of Europe. This did not stop the determined Heath from joining, but it did have the effect of creating suspicion in the minds of both Conservative and Labour supporters that membership might not be the economic saviour it had promised to be. It was also felt that, in his haste and determination to join, 
Heath and his negotiator, Geoffrey Rippon, had negotiated a bad deal. Britain had not, it was claimed, gained enough protection for the Commonwealth, were paying too much in contributions and was getting a poor return from the Common Agricultural Policy. Despite the misgivings. Britain joined and became a member of the EEC on 1 January 1973.

In the general election campaign of February 1974, Labour argued that Heath had made too many concessions. Wilson therefore promised that, if elected, he would consider leaving the Community.

\section{The 1975 referendum}

Having won both elections of 1974, Wilson was true to his word and began to prepare for withdrawal. However, he soon realised that leaving the community might be a worse option than staying in. He therefore decided to try to renegotiate British terms and persuade the British people that the change of policy was justified.

Changing policy had created huge problems for Wilson. The Labour party was hopelessly split over British membership, largely along left-wing-right-wing lines, with the former opposed. The referendum idea was therefore very attractive. If Wilson could secure a 'yes' vote for membership he could outflank his opponents.

New terms were negotiated by Chancellor of the Exchequer, Jim Callaghan. Slightly lower contributions were arranged and an improved deal for agriculture agreed. Wilson was able to present a better package to the electorate in the referendum campaign.

The 1975 referendum campaign was an unusual time in British political life for a number of reasons:

- It was the first time a fully national referendum had been held on a political issue.

- Because the cabinet itself was split on British membership, Wilson did a deal with the 'no' Lobby that collective responsibility would be suspended. Cabinet members were free to speak their minds on the issue without any constraints. This was on the understanding that both sides would accept the verdict of the people.

- Special rules were made which ensured that both sides in the campaign were only allowed the spend a limited amount. This was designed to ensure a balanced contest. It was the first time a political campaign had been controlled by law.

The result - a win for the 'yes' campaign by 66-34 per cent - was mercifully decisive and the controversy subsided. The government survived both the 
U-turn in policy and the bitter internal divisions which had threatened its survival. It is an ironic fact that the issue which Labour survived in 1975 Britain's relations with Europe - was the same one which was to tear the Conservatives apart in the 1990s and consign them to two enormous election defeats in 1997 and 2001.

\section{BRITISH PARTIES AND THE EU}

The events of 1974-75 and of 1992-97, when British involvement in Europe cut across party lines, threatened the political stability of the country in these two periods. Some basic principles need to be identified to explain why Europe has proved to be so divisive.

1 The left wing of British politics sees the EU as a free-trade area which operates to the benefit of producers and employees at the expense of workers and consumers. It is therefore deeply opposed to its principles.

2 The right wing of the political spectrum view Europe as a socialist experiment, designed to establish uniformity and bureaucracy which are opposed to the ideals of business and place the interests of workers above those of entrepreneurs.

3 Liberals have seen the EU as an opportunity to decentralise some powers in a 'Europe of the regions'. Conservatives, by contrast, believe that Europe means increasing centralisation in Brussels. This will therefore enhance democracy, they argue, whereas many Conservatives see the EU as anti-democratic.

4 Many Conservatives are strong British nationalists. They believe Europe threatens the sovereignty of the UK.

5 Campaigners who are interested in the environment and the economic plight of the third world see the European Union as part of a global multinational movement which places rising prosperity in the west above the interests of the world as a whole.

6 Supporters of the EU, who come from all parties and who are essentially pragmatists, believe that economic integration is inevitable, a part of the process of globalisation. They therefore see opposition to the EU as futile.

7 Nationalists in the UK, such as the SNP and Plaid Cymru are generally proEuropean. They argue that the EU will give them a better deal than the United Kingdom has done. In other words they believe they can have a louder voice in Brussels than they have had in London.

This extensive set of attitudes demonstrates how fragmented political opinion is on European issues. Small wonder then, that it is a major issue both between the parties and within parties. 


\section{Labour}

For most of the period following the Treaty of Rome in 1957, Labour had been opposed to British membership. Labour had always been something of an isolationist party, unwilling to become involved in world affairs. The disaster of the Suez expedition in 1956, which Labour had opposed and which humiliated the Eden government, confirmed their suspicion of an international role for Britain. In the 1960s the Wilson government had refused to become involved directly in the Vietnam war, was granting independence to many of the colonies and initiated the 'east of Suez' policy. This last principle stated that Britain should withdraw from any major involvement beyond the middle east.

It was therefore hardly surprising that there was little enthusiasm in the party for EEC membership. When Wilson applied for membership in 1966-67, he could not be sure of carrying his party with him, so the French veto came as something of a relief.

In the 1975 referendum campaign on membership, Labour was split and only stayed together through the clever device of consulting the people directly. At that time and ever since, Tony Benn, the venerated left-winger, led the section of the party which was opposed to European involvement. As we have seen above, his view and that of his allies was that it was a capitalist enterprise, with little in it for consumers and workers. During the 1980s, official policy was suspicious of Europe, but since the Conservatives were totally dominating the political scene at that time, Labour's attitude to Europe counted for little.

But as the New Labour movement emerged in the 1990s under John Smith and Tony Blair, the party's attitude to international affairs in general began to change. Blair in particular believed that Labour would have to give up its traditional isolationism and accept that the world was becoming increasingly interdependent. Europe was here to stay and any modern state had to adapt to the challenges of globalisation. Labour now looked in both directions in its new internationalist outlook. As the relationship with the USA warmed after Labour came to power, the party embraced the European Union. Opponents of closer integration became an increasingly marginalised and irrelevant minority.

Labour inherited the Maastricht opt-out from the single currency from John Major in 1997. The questions for them now were:

- when to join the single currency;

- how to prepare for entry;

- how to prepare public opinion for entry.

There were small differences in emphasis over timing between those who were cautious and those who wanted to rush in as soon as possible. However, the leadership was united in the belief that entry into the single currency was both desirable and inevitable. By 2002, therefore, the nation waited for the Labour 
government to announce the date of a referendum. In the meantime Gordon Brown and Tony Blair continued to spar over what constituted the 'right moment'. Both agreed that the conditions had to be favourable, but there remained the question of what were these 'conditions'?

\section{Conservatives}

Britain's involvement with Europe has proved a painful experience for the Conservative party producing a basic split in the party between two considerations.

- Pragmatists in the party have long since believed that, like it or not, Britain's long-term best interests lie in Europe. Despite the country's traditional links with the USA and the Commonwealth, Britain could not resist the inevitable closer integration of Europe. Among the leading members of this group have been Geoffrey Howe (cabinet minister in the 1980s) and Michael Heseltine (a leading member of the 'liberal' wing of the party).

- A significant minority have been Euro-enthusiasts. They see no contradictions in British involvement, are fundamentally pro-European and see the single currency as the logical conclusion of integration. Key figures here have been former prime ministers Ted Heath and John Major, and exChancellor, Kenneth Clark.

- Perhaps the largest group have been euro-sceptics. Led famously by Margaret Thatcher (especially from 1989 onwards), this group supports continued membership up to the terms of the Maastricht reforms of 1992. However, they oppose any further political union which would lead to further losses of sovereignty. They also believe that it is unlikely that conditions will ever exist where Britain should join the single currency (though some do not rule it out altogether).

- A small group of Euro-phobes wish to see Britain withdraw from the European Union. Thatcher seemed to be joining this group after her retirement from politics in 1997. She allied herself with such figures as Bill Cash and John Redwood. It is suspected that Iain Duncan Smith, who became leader in 2001, may have been a part of this group, but, as leader, he cannot afford to admit to such an extreme view.

The complete failure of the Conservative party to heal its internal divisions and to find some kind of compromise position which could at least paper over the cracks, has placed it in danger of oblivion.

During the 1992-97 government of John Major the party tore itself apart over Europe. Cabinet collective responsibility broke down and the government tottered from one crisis to the next. Major could not rely on any solid support and was constantly undermined by the euro-sceptics and anti- 
Europeans. Major negotiated opt-outs from the Social Chapter and the single currency at Maastricht in 1992, but this did not satisfy the sceptics. They took every opportunity to make life difficult for Major, even on non-European issues.

Labour's crushing defeat of the Conservatives in 1997 had a number of causes, but the split over Europe was of great importance. When the party continued its internal feuding over the next four years, a second defeat became inevitable. After 2001 Duncan Smith tried to move the party away from Europe, but the expected referendum on the single currency threatens to reopen the old wounds.

\section{Liberal Democrats}

The Liberal Democrats (and their predecessors the Liberal and Social Democrat Parties) have always been largely united in their support for the European Union and, more recently, British participation in the single currency. There are a number of reasons for this enthusiastic support:

- Liberals are attracted by the freedoms created by a single market.

- The European Union offers strong protection for consumers, workers, social security claimants and all those who wish to trade on fair terms. These are ideals which Liberals support.

- The European Union political system seems to offer greater power to regions. Liberals favour such decentralisation.

- European countries have a stronger tradition of human rights protection than Britain. They therefore hope that the rights culture will be imported into Britain with closer involvement.

There is something of a paradox in Liberal democrat support for the European project. The democratic deficit which is said to exist in European political institutions should put Liberals off. They are strong democrats and so ought to be suspicious of the centralised, rather unaccountable European bureaucracy. But this does not outweigh what they perceive to be great advantages. Furthermore, they believe that closer British involvement will be a strong democratic influence on the other members.

It may be that, in a future referendum campaign on the single currency, the Liberal democrats may tip the balance of power towards a 'yes' vote.

\section{Nationalists}

The Scottish and Welsh nationalists are strong supporters of closer political integration in Europe. The believe that the European Union represents a weakening of the nation-state. Since they wish to see transfers of power away 
from the British state to their own countries, Europe provides them with the hope of greater autonomy.

Those nationalists who aim for full independence also see the EU as a means by which they could become economically viable. On their own, Scotland and Wales might not be able to sustain full economic independence, but in Europe they would benefit fully from regional policies of the kind which have produced an economic renaissance in the Republic of Ireland. With their own voice in Europe, an independent Scotland or Wales would be able to negotiate advantageous terms, rather than rely on the British government and its ministers.

Both the SNP and Plaid Cymru, therefore have campaigned hard for closer political union and a single currency. The more integrated Britain is with Europe, they hope, the more likelihood there is that they will be granted greater independence.

\section{Minor parties}

Two small anti-European parties have made some impression in Britain. These are the Referendum Party and the UK Independence party (UKIP).

The Referendum party was formed and financed by the multi-millionaire James Goldsmith. He pumped an estimated $£ 20$ million into the 1997 election campaign. Although the main platform of the party was to hold a referendum on continued British membership, it was clear that its supporters were antiEuropean. The party won no seats in 1997 and failed to make a significant impact on the results. Goldsmith died shortly after the election and the party disappeared.

Of a more permanent nature is UKIP, which is openly anti-European. This party has a small, but determined membership and fought both the 1997 and 2001 elections. Like the Referendum party it did not affect the results significantly. Indeed, if anything it helped to split the anti-Europe vote with the Conservatives and so helped Labour and Liberal democrat candidates. Nevertheless, it has survived and may gather strength in the future.

\section{FURTHER POLITICAL EFFECTS OF MEMBERSHIP}

\section{The constitution}

Membership of the EU and the gradual transfer of powers to Brussels has had a dramatic effect on the British constitution. We can identify the following features.

1 A significant part of the constitution is now codified. Those elements which deal with Britain's relationship with the EU are contained in the Treaties and 
agreements which have been agreed. Thus the Treaty of Rome, the Single European Act, and the Treaties of Maastricht, Amsterdam and Nice are now, effectively, part of the constitution. The terms of these agreements are binding on parliament and government.

2 Because the agreements identified above and owing to the principle that European law is superior to national laws, the sovereignty of parliament has been eroded. While it is true that Britain can retrieve its full sovereignty by leaving the EU, as long as we are a member, Europe can overrule parliament on any issue which requires only a majority vote in the Council of Ministers. A constitutional certainty which has existed for over three hundred years has, therefore, been diminished.

3 Rights in Britain have always been more vulnerable than in the rest of Europe. The power of government and the sovereignty of parliament have meant that it has been difficult to safeguard the rights of citizens. The European Union has introduced a wide range of rights for workers, consumers and recipients of welfare benefits. Enforced by the European Court of Justice, various European Acts are now effectively entrenched in British law.

4 British courts must now bow to the superior status of the European Court of Justice where European laws are concerned. The House of Lords is no longer the ultimate court of appeal in many cases. This role has now been transferred to Europe.

\section{Parliament}

Britain has made remarkably few changes to the structure and operation of parliament to accommodate membership of the European Union. Both the Commons and the Lords have select committees whose role is to examine proposals coming from the European Commission, but they have little influence over ministers and are seen as the minimum concession which could be made to membership.

Of course the great European issues are regularly debated in parliament. Indeed, some of the great parliamentary moments of the 1990s were provided by battles to approve of the Maastricht Treaty. In the future, conflict over the single currency are likely to provide more periods of high drama.

However, the more specialised policy areas of the EU, such as the Common Agricultural Policy, foreign policy, environmental protection and regional development do not receive a great deal of debating time in parliament. Discussion on these policies tends to take place within government other institutions. 


\section{Pressure groups}

There are five main types of pressure group which have been most affected by the EU. These are:

- trade unions;

- environmental groups;

- producer groups;

- farming interests;

- fishing interests.

Trade unions have been cautiously supportive of British involvement. They have been encouraged especially by the beneficial influence the EU has had on workers' rights. Working hours, holiday entitlement, pension rights, health and safety, part-time workers' rights and women's equality are all examples of improvements to the conditions of workers which have emerged from the EU.

British unions have federated themselves with their European colleagues and play their part in pressing the Commission for more worker-sympathetic legislation. They are, of course, confronted by commercial and industrial interests, but the EU has shown itself to be most sympathetic to workers' rights.

Environmental problems do not usually recognise national borders, so the environmental lobby, led by Friends of the Earth and Greenpeace (backed by European Green parties) is anxious to place pressure of European institutions. By influencing European legislation, environmentalists can hope to see benefits throughout Europe, not just in a single member state.

The kind of issues where environmentalists have sought action are genetically modified foods, coastal waters and river quality, species conservation, emissions and nuclear safety. As with unions the main environmental pressure groups are now European (as well as global) in their organisations.

Business groups in Britain have been largely in favour of membership, greater integration and the single currency. The creation of the single market has created new opportunities and reduced costs in general. However, the European Union has also brought many new regulations over such features as employment, health regulations, safety, consumer protection and trade conditions. To some extent business groups (largely manufacturing and commercial federations) have been engaged in holding back the tide of regulation, though, realistically, they have tried to obtain concessions in these areas.

On the finance side, too, banking and other institutions have sought to place pressure on the European Central Bank and the finance sections of the Commission, again to reduce regulation and to open up markets.

Farmers have proved to be an especially powerful interest in the European Union. It has to be remembered that European farming is more extensive 
than in Britain, but British farmers have, in some areas, ridden on the back of their more powerful European partners. On occasions, however, British farming interests have come into conflict with the rest of Europe. When British beef exports were banned for example, following the BSE scare, the National Farmers Union worked as hard as the government in trying to have the ban lifted.

The Common Agricultural Policy remains the main target for the British farming lobby. The CAP distributes subsidies, price supports and quotas throughout the community. British farmers are in competition for these benefits with other European farming groups. This leads to intense activity in Brussels, especially when the Council of Agricultural Ministers is about to meet. However the National Farmers Union also keeps a permanent organisation in place to lobby the Commission.

Fishing interests are in a similar position to the farmers. They ally themselves with other European fisherman to gain favourable policies for the industry as a whole. These concern the conservation of fish stocks, subsidies for some sectors of the industry and a variety of regulations concerning the way the fish are caught. But they are also in competition with the fishing industries of other countries. Fish quotas have to be distributed and the British campaign in Brussels for their fair share.

In addition to these main organisations, there is also a large collection of lobby groups operating in Europe in the fields of consumer protection, transport, trade, welfare, rights, law and order and the like. The recognition that an increasingly large number of decisions are now being made in Brussels has forced British pressure groups to move their operations across the Channel and to co-operate with their counterparts in other member states.

\section{The media}

The schism in British politics over Europe is reflected in the tabloid press. While the Sun remains largely euro-sceptic, the Mirror is enthusiastic for both integration and the single currency. When the referendum of the single currency is held, it is clear that these and other tabloids will play a major role.

Not surprisingly the broadsheet newspapers take a more measured view. Traditional Conservative-supporting papers like the Telegraph, the Daily Mail and the Express have argued against further integration, while the others, such as the Times, Independent and Guardian have tended take a more detached view, printing both sides of the case and refusing to make a firm commitment either way. In the referendum to come, they will probably have to come off the fence. In 2002 it seemed likely that most of the broadsheets are likely to favour entry into the euro-zone. 
The broadcast media are required by law to be neutral as this is a partly political issue. However, debate on Europe has become one of the most common subjects for current affairs programmes. They may not be allowed to lead public opinion, but they may prove to be the main source of information for the electorate.

\section{THE ECONOMY AND THE SINGLE CURRENCY}

The effects on economic policy making of British membership in an increasingly integrated Europe can be divided into three main aspects. These are: firstly, the ways in which the British government no longer has freedom of action because of the superiority of European laws; secondly, the need to meet the so-called 'convergence criteria' which will enable Britain to join the single currency system; finally, policy making must bear in mind the Labour government's five 'economic tests' which will determine the time when an application to join the euro-zone could be made.

\section{Policy making}

A number of options in economic management have been taken out of the hands of domestic governments, including Britain's.

- The ability to introduce import tariffs to protect one of our home industries. Britain must accept the fact that the EU is tariff free and that tariffs on goods coming from outside the EU are determined in Brussels.

- Similarly there are strict limits upon the amount of subsidies which can be given to certain industries. There are subsidies available from the EU, but the destination of these funds is determined in the EU itself. So regional economic policy is very much European controlled.

- Although member governments remain free to set their own levels of indirect taxation, such as VAT and excise duties, it has become clear that they cannot be allowed to vary greatly from levels which prevail in the rest of Europe. Because there is now completely free trade, high levels of indirect taxation in the UK compared to the rest of Europe would damage the sale of goods to visitors from abroad. The tourist industry would suffer excessively.

- Financial markets in Europe are now extremely free and open. Though the Bank of England can set its own interest rate and the government is free to manage credit controls, in practice the British financial markets must be kept reasonably in line with the rest of the EU. 
Similarly, levels of income and corporate taxes (on profits) are still in the hands of the national government. But, because both workers and businesses now have completely free movement within the EU, Britain could not afford to set higher than average tax levels. If we did we might experience a movement of workers and businesses away from the UK to countries where taxes are lower.

In summary, therefore, we can say that some aspects of independent economic policy making have been removed, while others have become heavily influenced by the realities of European integration.

\section{Convergence}

The countries which have wished to enter the single currency system have been required to meet a number of 'convergence criteria'. These 'rules' are designed to ensure that the economies of member countries are reasonably in step with each other. By being so 'converged' there is less disruption caused by adopting the same single currency.

Britain has a long-term intention to join, so the Labour government which came to power in 1997 decided to pursue the convergence criteria in readiness for joining. The criteria include maximum levels of inflation and public borrowing, low unemployment, low interest rates and reductions in the level of accumulated or 'national' debt.

For Britain the targets on inflation, unemployment and interest rates seemed to occur naturally as the economy recovered from recession and entered a period of steadily growing prosperity. The high levels of government borrowing, however, needed positive action. Faced with the need to increase spending on public services in 1997-2000, Chancellor Gordon Brown chose, nevertheless, to pay back large portions of the national debt and avoid any short-term borrowing. In some ways he sacrificed some short-term spending options, in order to meet the criteria on debt. In other words, he favoured long-term benefits at the expense of short-term gains.

By 2000, therefore, Britain had achieved the criteria with a good deal to spare. Since then it has been necessary to try to ensure that the economy did not stray from the rules. Up to 2002 at least, this proved relatively comfortable. It may not always be so.

\section{The five economic tests}

These are Britain's own criteria for entry into the single currency. They are:

1 Membership must be favourable to inward investment into the UK (i.e. foreign companies setting up in the UK). 
2 It must not threaten Britain's leading role in financial markets.

3 Britain's natural economic cycle will have to be reasonably in line with that of the euro-zone. In other words the levels of growth, inflation, unemployment and interest rates will need to be close to those existing in the rest of Europe.

4 Will there be a reasonable amount of flexibility to allow Britain to join on favourable terms?

5 Will membership be of long-term benefit to the British economy, especially terms of employment, growth and economic stability?

Many of these conditions do not require specific policy making, so they may not influence economic management directly. However, they remain influential. It may be that, as membership of the single currency seems to be imminent, the government may attempt to manipulate the exchange value of sterling, the level of public borrowing and the level of growth, so that Britain joins at the most favourable moment, according to these membership conditions.

\section{THE FUTURE OF BRITISH MEMBERSHIP}

\section{The single currency}

If Britain joins in the future, it is likely to be permanent and will certainly have far-reaching effects. It is, therefore, certainly the most important decision in the foreseeable future.

The effects of membership include loss of control over the setting of interest rates, much less flexibility in taxation policy and government fiscal budgeting, little control over credit restrictions and a general harmonisation of economic policy making with Europe as a whole. In other words it would represent a major 'sacrifice' or 'pooling' (depending on one's point of view) of sovereignty for Britain. We would also have to accept that decisions made by the European Central Bank and the Council of Finance Ministers will affect the performance of the British economy.

On a more general level, membership of the euro-zone will be heavily symbolic. It will be a powerful signal that Britain has finally abandoned its suspicions of membership.

\section{Political integration}

The Blair government has made it clear that it will oppose any further political integration unless the problem of the democratic deficit is tackled. Indeed, by 2002 Britain led the section of the EU which opposes further moves towards federation. 
Should the Conservative party regain power, the prospects for closer union will become even more remote. It will require a major shift in public opinion for any British government to support a deeper union. So, for the time being Britain wants the EU to remain an intergovernmental organisation, rather than a supranational one.

Having said that, the Labour government has played a leading role in promoting integration in foreign and defence policy and is broadly in favour of further steps to harmonise policies on law and order, rights and immigration. These have become especially pressing issues as enlargement is just around the corner. In summary, therefore, current thinking is in favour of more integration of policy, but much less so in terms of institutions.

One final issue should be clarified. Despite the persistence of a sizeable minority on the right of British politics who want the country to leave the EU, there is little prospect of departure. British membership appears to be here to stay.

\section{SAMPLE QUESTIONS}

1 What have been the main effects of British membership of the EU on the political system?

2 How does membership of the EU affect the conduct of economic policy making in Britain?

3 How has the issue of Europe influenced British party politics?

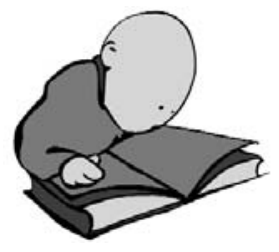

